Коваленко В.Л., Кузнецова Е.В., Кузнецов В.В.

Особливості впровадження біогазових технологій в умовах промислових підприсмств металургійної галузі Kovalenko V. Kuznetsova E., Kuznetsov V.

\title{
Features of introduction of biogas technologies in the conditions of industrial enterprises of the metallurgical industry
}

\begin{abstract}
В роботі проаналізовано та класифіковано переваги та недоліки існуючих технологій очищення від сірководню та підвищення калорійності збагаченням біогазових сумішей з різних джерел. Серед них визначено ті, що найбільш прийнятні з економічної точки зору для впровадження у важкій промисловості. Встановлено перелік доступних методів та відносно не затратних реагентів для обробки біогазу в умовах металургійних підприємств, серед яких слід виділити технічну та аміачну воду, відходи процесів травлення сталі у вигляді сульфату заліза та інші. Проведено порівняння основних паливних характеристик біогазу різного походження $i$ складу та природного газу при визначенні напрямків використання альтернативного палива в нагрівальних промислових установках.

Визначено, що термічні та нагрівальні печі мають найбільший потенціал на пристосування до спалювання біогазу, оскільки такі агрегати здатні працювати в широкому діапазоні якості, витрати та калорійності палива. Оскільки наукова база щодо можливого переведення зазначених установок на біогаз має неструктурований характер, а у багатьох аспектах відсутня, створення відповідних методик, математичного апарату та алгоритмічних засобів в даному напряму $є$ актуальною задачею.

Ключові слова: енергоефективність, біогазові технології, біогаз, природний газ, очищення, збагачення, промислові печі, економічна доцільність
\end{abstract}

\begin{abstract}
The paper analyzes and classifies the advantages and disadvantages of existing technologies for cleaning hydrogen sulfide and increasing calorific value by enriching biogas mixtures from various sources. Among them are identified those that are most acceptable from an economic point of view for implementation in heavy industry. A list of available methods and relatively inexpensive reagents for the treatment of biogas in the conditions of metallurgical enterprises, among which technical and ammonia water, waste from steel pickling processes in the form of iron sulfate, and others, is established. The main fuel characteristics of biogas of various origin and composition and natural gas are compared in determining the directions of using alternative fuel in industrial heating plants.

It was determined that thermal and heating furnaces have the greatest potential for adaptation to biogas combustion, since such units are able to work in a wide range of quality, fuel consumption and calorific value. Since the scientific base regarding the possible conversion of these plants to biogas is unstructured, and in many aspects is absent, the creation of appropriate methods, mathematical apparatus and algorithmic tools in this direction is an urgent task.

Keywords: energy efficiency, biogas technologies, biogas, gas, purification, enrichment, industrial furnaces, economic feasibility
\end{abstract}

Вступ. Ефрективність використання енергоресурсів $є$ одним з найважливіших показників ефективності підприємства в цілому, особливо для металургійних та машинобудівних комбінатів, з характерною для них великою енергоємністю виробництва. Головним видом палива для промислових енергетичних установок, таких як печі, котли, двигуни та турбіни продовжує використовуватись природний газ, заміщення якого становиться однією з головних стратегічних цілей.

Питання використання альтернативних та відновлюваних джерел енергії в промисловості з кожним днем набуває більшої актуальності. Вдало реалізуються проекти заміщення природнього газу низькокалорійним газоподібним паливом на існуючому обладнанні. Однією з таких альтернатив може стати біогаз.

В сучасних умовах, у ливарних цехах металургійних підприємств споживання природного газу складає більше $50 \%$ від загальних витрат енергоресурсів. Разом з цим існують всі передумови використання біогазу як альтернативного палива в основних агрегатах ливарних цехів. У загальному вигляді, повний замкнений цикл виробництваспоживання біогазових сумішей в промислових умовах схематично може складатися 3 основних блоків (рисунок 1): джерело сировини, виробництво біогазу, приведення до необхідної якості, споживання.

Крім метану, в щойно виробленому (сирому) біогазі містяться також інші важливі компоненти [1], об'ємні концентрації яких наступні: вуглекислий газ $\left(\mathrm{CO}_{2}\right.$ : до $\left.50 \%\right)$, азот $\left(\mathrm{N}_{2}\right.$ : до $\left.10 \%\right)$, кисень $\left(\mathrm{O}_{2}\right.$ : до $2 \%)$, водень $\left(\mathrm{H}_{2}\right.$ : до $\left.2 \%\right)$, сірководень $\left(\mathrm{H}_{2} \mathrm{~S}\right.$ : до $1,5 \%$ ). Також в незначній кількості можуть спостерігатись у складі водяна пара, вищі гідрокарбонати, силоксани та хлор. Склад сирого біогазу також залежить не тільки від виду сировини, але й технології для його виробництва. Головні джерела біогазового виробництва для потреб промисловості $€$ полігони ТПВ й стічні води, а також біоконвертований послід свійських тварин і відходи харчової промисловості. Типовий склад біогазу, відповідно до кожного з цих видів сировини, наведено у таблиці 2 [2].
Коваленко Віктор Леонідович к.т.н.,доц. ЗТУ

Кузнецова Аліса Віталіївна - ДНУ

Кузнецов Віталій Вадимович - к.т.н., доц. НМетАУ.В.
Kovalenko V. - Ph.D., Assoc. Prof. ZTU

Kuznetsova E. - DNU

Kuznetsov V. Ph.D., Assoc. Prof. NMetAU 


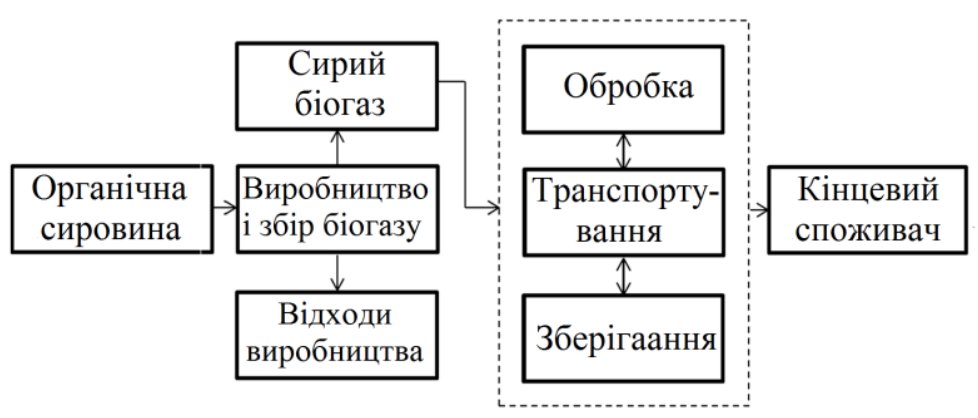

Рисунок 1 - Блок-схема циклу виробництва-споживання біогазу

Таблиця 1 - Типовий об'ємний склад біогазу з потенційних для промисловості джерел сировини

\begin{tabular}{|l|l|l|l|}
\hline Компонент & $\begin{array}{l}\text { Одиниця вимірю- } \\
\text { вання }\end{array}$ & $\begin{array}{l}\text { Стічні води та } \\
\text { ТПВ }\end{array}$ & $\begin{array}{l}\text { Відходи органічного } \\
\text { походження }\end{array}$ \\
\hline Метан & $\%$ & $45-60$ & $55-70$ \\
\hline Двоокис вуглецю & $\%$ & $25-50$ & $25-45$ \\
\hline Водень & $\%$ & $0-3$ & $0-1$ \\
\hline Азот & $\%$ & $2-10$ & $0-1$ \\
\hline Кисень & $\%$ & $0-3$ & $0-0,5$ \\
\hline Сірководень & $\%$ & $0-1$ & $0,2-1,5$ \\
\hline Вищі гідрокарбонати & $\%$ & $<0,5$ & $<0,5$ \\
\hline Силоксани & $\%$ & $<0,2$ & 0 \\
\hline Оксид вуглецю & $\%$ & $<0,5$ & 0 \\
\hline
\end{tabular}

Як видно з таблиці 1, в біогазі в різних кількостях можуть знаходитись основні компоненти. Важливою відмінністю біогазу, зібраного на полігонах ТПВ та отриманого з осаду стічних вод, є ймовірність підвищеного вмісту в ньому баластних домішок, таких як азот та вуглекислий газ, а вміст метану в середньому становить половину об'єму газової суміші. В свою чергу, біогаз з продуктів життєдіяльності тварин та органічних відходів рослин- ного походження відрізняється вищою калорійністю, проте, і підвищеним вмістом сірководню. Як видно, яким би не було джерело біогазових сумішей, цьому енергоресурсу притаманні значні недоліки у вигляді шкідливих домішок у складі палива. Останні чинять різний вплив на системи використання таких технологій. В таблиці 2 наведено загальний характер впливу основних небажаних домішок в біогазі на різноманітне обладнання [1]. Таблиця 2 - Види шкідливих домішок в біогазі та характер їх впливу

\begin{tabular}{|c|c|c|}
\hline $\begin{array}{l}\text { Вид домі- } \\
\text { шок }\end{array}$ & Джерело утворення & Характер впливу \\
\hline $\mathrm{CO}_{2}$ & $\begin{array}{l}\text { Мінералізація вуглецю органічної } \\
\text { речовини при біоконвертації }\end{array}$ & $\begin{array}{l}\text { - зниження загальної калорійності суміші, } \\
\text { - зниження ефективності використання енергії палива; } \\
\text { - призведення до невідповідності технологічним ре- } \\
\text { жимам; } \\
\text { - погіршення теплових балансів агрегатів; } \\
\text { - зниження рівня детонації та стійкості горіння. }\end{array}$ \\
\hline $\mathrm{H}_{2} \mathrm{~S}$ & $\begin{array}{l}\text { Продукт переробки білків у проду- } \\
\text { ктах життєдіяльності тварин та } \\
\text { рослинних відходах метаноутво- } \\
\text { рюючими мікроорганізмами }\end{array}$ & $\begin{array}{l}\text { - спричиняє корозію кольорових металів, чистих спла- } \\
\text { вів та алюмінію в газоспоживаючому обладнані; } \\
\text { - призводить до перекислення мастил та емісії } \mathrm{SO}_{2} \\
\text { при спалюванні; } \\
\text { - перекислення мастил та утворення осаду. }\end{array}$ \\
\hline $\mathrm{N}_{2}$ & $\begin{array}{l}\text { Доступ повітря до джерела утво- } \\
\text { рення або транспортування біога- } \\
\text { зу до споживача }\end{array}$ & $\begin{array}{l}\text { призводить до збільшення антидетонаційних власти- } \\
\text { востей біогазу. }\end{array}$ \\
\hline $\begin{array}{l}\text { Силокса- } \\
\text { ни }\end{array}$ & $\begin{array}{l}\text { Косметичні речовини та консерва- } \\
\text { нти }\end{array}$ & $\begin{array}{l}\text { призводить до старіння рухомих частин обладнання } \\
\text { Внаслідок утворення кварцевих частинок кремнезему; } \\
\text { осаджується на поверхні контактуючих матеріалів } \\
\text { продуктами згоряння. }\end{array}$ \\
\hline $\mathrm{CO}$ & $\begin{array}{l}\text { Розклад лігніноцелю-лозних ком- } \\
\text { плексів при підвищених темпера- } \\
\text { турах та не достатньому доступі } \\
\text { кисню }\end{array}$ & $\begin{array}{l}\text { - екологічна небезпека, отруйність; } \\
\text { - утворення з водою корозійних речовин. }\end{array}$ \\
\hline
\end{tabular}


Показник вмісту метану (до 70\%) в сирому біогазі відносить його до класу низькокалорійних палив, проте він може стати потенційною альтернативою для української промисловості. Головною його характеристикою, як і будь-якого виду палива, $€$ теплота згоряння або нижча теплотворна здатність $Q_{H}^{p}$. Якщо об'ємний процентний вміст

$$
Q_{H}^{p}=358,2 \cdot \mathrm{CH}_{4}+235 \cdot \mathrm{H}_{2} \mathrm{~S}+108 \cdot \mathrm{H}_{2} .
$$

Залежно від вмісту метану та інших компонент в такому паливі, $Q_{H}^{p}$ сирого біогазу перебуває в межах 17-26 МДж/м³ [1]. Метан, що міститься в біогазі має температуру запалення у $645^{\circ} \mathrm{C}$ [4], а для сирого біогазу збільшується в залежності від підвищення вмісту баластних, проте не шкідливих домішок, таких як $\mathrm{CO}_{2}$ та $\mathrm{N}_{2}$, та досягає позначки в $700-720^{\circ} \mathrm{C}$, що $є$ негативним фрактором. Також, виключне значення для прийняття рішення щодо використання біогазових сумішей в енергозабезпеченні промислового обладнання має температура горіння $T_{b}$, оскільки остання визначає особливості режимів його роботи. У [4] визначено, що такі головні домішки, як сірководень, водень, кисень, не суттєво впливають на цей показник. В більшій мірі, тільки вуглекислий газ, азот й водяна пара мають вплив на процес спалювання та теоретичну температуру горіння біогазових сумішей. Аналітичний зв'язок між теоретичною температурою горіння $T_{b}, K$ та вмістом $\mathrm{CO}_{2}, \mathrm{H}_{2} \mathrm{O}$ та $\mathrm{N}_{2}$ в метані представлено на рисунку 2, з якого видно, що залежність $T_{b}$ від збільшення частки відповідної домішки у метані є нелінійною-спадаючою.

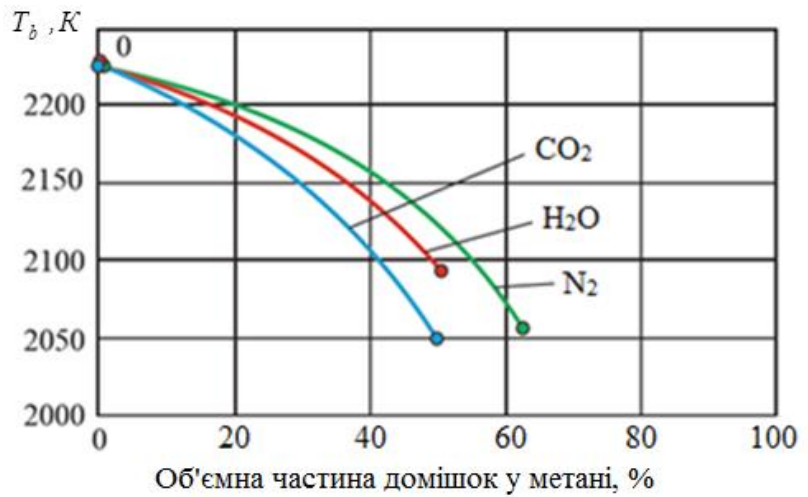

Рисунок 2 - Вплив домішок на теоретичну температуру горіння біогазу

В [5] визначено, що дійсна температура горіння, на відміну від теоретичної на $7 . . .10 \%$ менше та знаходиться в межах 1900 - 2100 К, в залежності від складу біогазу та кількісного вмісту в ньому основних компонент. Крім того, у біогазі в порівнянні з природним газом, набагато нижча максимальна, через вміст баластних домішок, нормальна швидкість поширення полум'я, яка теоретично може бути визначена за емпіричною формулою [6]:

$$
U_{b}=U_{H} \cdot\left(1-0,01 \cdot \mathrm{N}_{2}-0,012 \cdot \mathrm{CO}_{2}\right),
$$

де $U_{H}$ - швидкість розповсюдження полум'я чистої суміші, см/с.

Теоретично можна розрахувати основні паливні показники при заміні природного газу біогазовими сумішами: калорійність $Q_{H}^{p}$, нормальна швидкість поширення полум'я $U_{b}$, теоретична темпера- тура запалення та горіння - $T_{3}$ і $T_{b}$, відповідно, верхня та нижня концентраційні границі запалення $L_{\beta}$ та $L_{H}$, щільність біогазової суміші $\rho$, та число Воббе $\zeta$ - основна характеристика постійності теплового потоку згоряння палива. Останній показник використовують при оцінці якості газоподібних палив та можливості заміни енергоресурсів при збереженні технологічних вимог. Отже, розрахункові теоретичні значення цих показників для біогазу, в залежності від його складу, та природного газу наведені в таблиці 3.

Як видно з таблиці, збільшення концентрації баластних домішок суттєво погіршує паливні властивості біогазу порівняно із природним. Збільшення відхилення значення числа Воббе від притаманного природному газу означає ускладнення заміни одного палива іншим. Відхиляння на 5-6\% створює турбулентний потік [7], що покращує інтенсивність горіння, проте погіршує його стійкість. 
Таблиця 3 - Паливні характеристики біогазу та природного газу

\begin{tabular}{|c|c|c|c|c|c|c|c|}
\hline \multirow[t]{3}{*}{ Показник } & \multicolumn{6}{|c|}{ Біогаз } & \multirow[t]{3}{*}{ Природний газ } \\
\hline & \multicolumn{6}{|c|}{ Вміст баластних домішок в біогазі \% } & \\
\hline & 0 & 20 & 30 & 40 & 50 & 60 & \\
\hline $\begin{array}{ll}\text { Калорійність } & Q_{H}{ }^{p}, \\
\text { МДж/ }{ }^{3} & \\
\end{array}$ & 35,8 & 28,6 & 25 & 21,5 & 17,9 & 14,3 & $33-35$ \\
\hline $\begin{array}{l}\text { Швидкість поширення } \\
\text { полум'я } U_{H}, \mathrm{~cm} / \mathrm{c}\end{array}$ & 38,0 & 28,3 & 23,7 & 19,2 & 14,6 & 10,1 & $37-40$ \\
\hline $\begin{array}{l}\text { Температура запа- } \\
\text { лення } T_{3,}{ }^{\circ} \mathrm{C}\end{array}$ & 645 & 686 & 695 & 709 & 716 & 725 & 650 \\
\hline $\begin{array}{l}\text { Температура горіння } \\
T_{b,}{ }^{\circ} \mathrm{C}\end{array}$ & 1970 & 1909 & 1872 & 1827 & 1775 & 1700 & $1900-2000$ \\
\hline $\begin{array}{l}\text { Верхня границя за- } \\
\text { палення } L_{8,} \%\end{array}$ & 15 & 14,1 & 13,2 & 12,2 & 10,9 & 10,1 & 15 \\
\hline $\begin{array}{l}\text { Нижня границя запа- } \\
\text { лення } L_{H} \%\end{array}$ & 5 & 5,6 & 5,8 & 6 & 6,3 & 6,4 & 5 \\
\hline Щільність $\rho$, кг/м ${ }^{3}$ & 0,68 & 0,93 & 1,05 & 1,2 & 1,32 & 1,45 & $0,7-0,75$ \\
\hline $\begin{array}{l}\text { Число } \\
\text { МДж/м }\end{array}$ & 51,5 & 38,4 & 31,9 & 25,9 & 20,1 & 15,7 & $47-52$ \\
\hline
\end{tabular}

Спалювати щойно вироблений «сирий» біогаз також неефективно з технологічної точки зору та неприпустимо з екологічної. Через це біогазові технології потребують наявності на підприємстві додаткової системи обробки, рівень впровадження якої залежить від необхідності забезпечення багатьох факторів: відповідних вимог щодо використання палива; необхідності покращення основних паливних характеристик біогазової суміші; зменшення витрат на адаптацію обладнання для використання біогазу. Тому, не менш важливою задачею в питанні переведення обладнання на низькокалорійне паливо, $є$ необхідність підвищення відносного вмісту метану в паливі шляхом видалення баластних складових, зокрема вуглекислого газу, тобто «збагачення біогазу» до необхідної калорійності.

Умови використання біогазу в промисловості $€$ основоположним фрактором при визначенні методів його обробки та рівня їх впровадження [4]. Біогазові суміші можливо обробляти в декілька етапів з використанням різних технологій та відмінним кінцевим рівнем якості в залежності від мети та критеріїв застосування [8]. В таблиці 4 проаналізовано та класифіковано існуючі технології очищення біогазу від сірководню та підвищення загальної калорійності палива за допомогою збагачення.

Таблиця 4 - Технології обробки біогазу

Очищення (ресурси)
Очищення металовмісними реагентами (оксиди, гід-
роксиди та солі $\mathrm{Fe}, \mathrm{Cu}, \mathrm{Cr}$ )

Фільтрація легованим активованим вугіллям

Абсорбція рідкими активними речовинами (хінони метил- та діетаноламіни; аміачна вода)

Біологічні методи (спеціальні бактерії; ферменти)

Для визначення вигідних з економічної точки зору шляхів ліквідації цих ефектів, проаналізовано та класифіковано всі переваги та недоліки існуючих технологій очищення біогазу від сірководню та підвищення загальної калорійності палива за допомогою збагачення. Серед них обрано методи, які найбільш привабливі для впровадження у важкій промисловості та окреслено перелік доступних та дешевих ресурсів для обробки біогазу в умовах металургійних підприємств, таких як технічна та

Таблиця 5 - Екологічний ефект від видалення сірководню з біогазової суміші

\begin{tabular}{|l|l|l|l|l|l|}
\hline \multirow{2}{*}{ Показник } & \multirow{2}{*}{ Природний газ } & \multicolumn{4}{l}{ Вміст $\mathrm{H}_{2} \mathrm{~S}$ в біогазі, \% } \\
\cline { 3 - 7 } & & 0,1 & 0,3 & 0,5 & 1 \\
\hline Концентрація $\mathrm{SO}_{2}$ у викидах, мг/м & 0 & 210 & 370 & 750 & 1830 \\
\hline Питома емісія $\mathrm{SO}_{2}, \mathrm{kг} / 1000 \mathrm{~m}^{3}$ & 0 & 2,63 & 7,89 & 13,15 & 26,3 \\
\hline
\end{tabular}

Збагачення (ресурси)

Мембранна сепарація (плоскі або трубчасті полімерні мембрани; рідкі адсорбенти)

Рідинна абсорбція під тиском (вода; рідкі активні речовини)

Кріоадсорбційне розділення біогазу (холодильні агенти; теплова енергія)

Кріодистиляційне розділення біогазу (рідкий азот)

аміачна вода, а також відходи процесів травлення сталі у вигляді сульфату заліза.

При дослідженні ефективних напрямків використання біогазових технологій в промисловості, також проведено порівняння основних паливних характеристик біогазу різного ступеня очищення та природного газу (таблиця 3). Порівняння екологічного ефекту від зазначеної обробки наведено в таблиці 5. 
Встановлено, що термічні та нагрівальні печі найпростіше мають пристосовуватись до спалювання біогазу, оскільки відомо, що такі агрегати здатні працювати в широкому діапазоні якості та калорійності палива. Крім того, технологічні вимоги саме металургійних агрегатів до вмісту баластних домішок та шкідливого сірководню $є$ мінімаль- ними, при цьому мають зберігатись технологічні умови термічної обробки та забезпечуватись відповідні екологічні норми. Враховуючи вищесказане, на рисунку 3 наведено найбільш доцільні напрямки використання біогазових сумішей в умовах промислових підприємств.

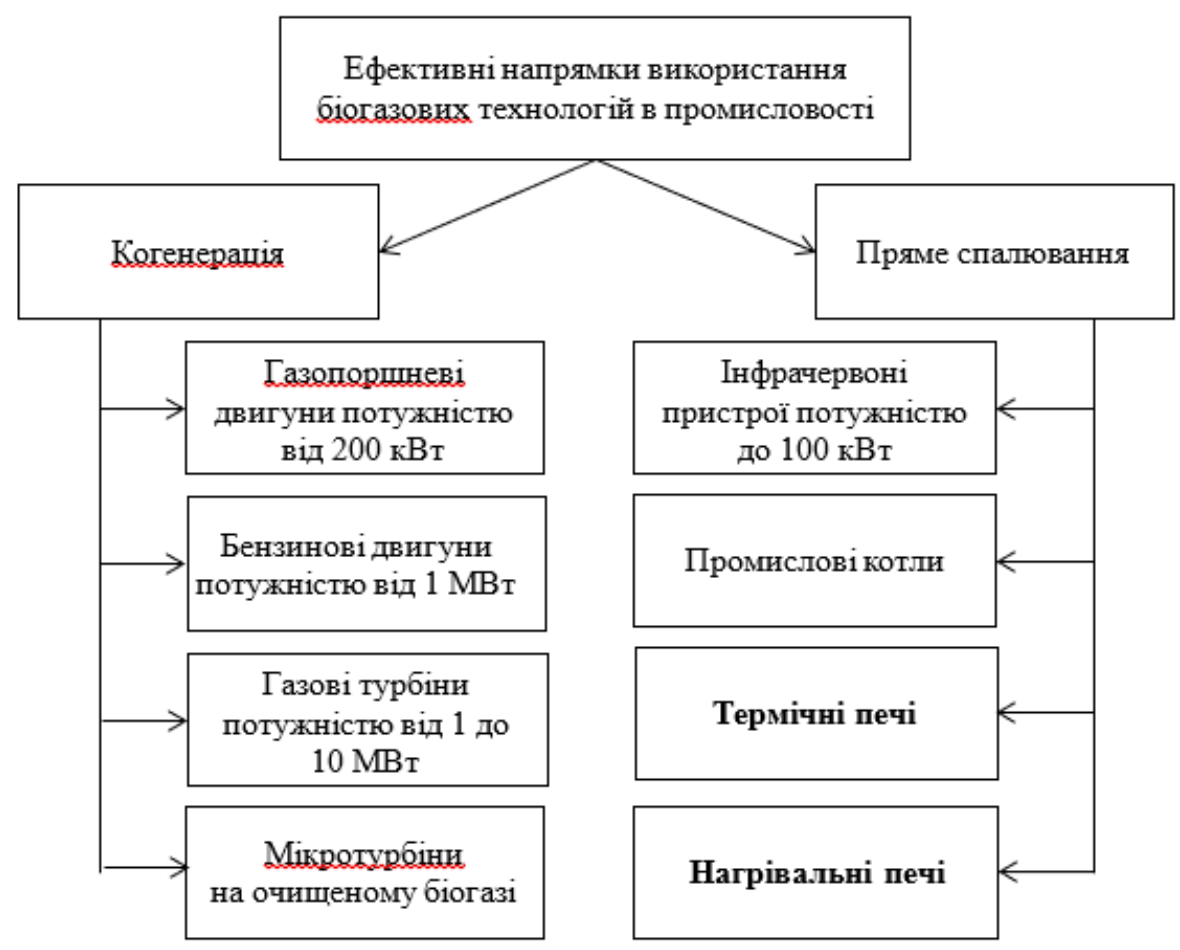

Рисунок 3 - Ефективні напрямки використання біогазових технологій в промисловості

Проте, модернізація пічного обладнання під низькокалорійні біогазові суміші вимагає, як мінімум, переобладнання пальникових пристроїв, а великий вміст домішок збільшує питому витрату палива, що призводить до збільшення операційних витрат, невідповідності режимів нагрівання та погіршує тепловий баланс агрегату. При цьому з екологічної точки зору при використанні біогазу низької якості необхідно враховувати додатково збільшення емісії диоксидів вуглецю та сірки й відповідні при цьому економічні збитки.

Отже, визначено, що термічні та нагрівальні печі мають найбільший потенціал для спалювання в них низькокалорійних палив і біогазу зокрема, оскільки такі агрегати здатні працювати в широкому діапазоні якості, витрати та калорійності пали- ва. Проте наукова база щодо переведення пічних установок на біогаз має неструктурований характер, а у багатьох важливих питаннях взагалі $є$ відсутньою. Встановлено, що збільшення концентрації баластних домішок суттєво погіршує паливні властивості біогазу порівняно із природним газом. Для визначення вигідних з економічної точки зору шляхів ліквідації цих ефректів, класифіковано існуючі технології очищення біогазу від сірководню та його збагачення задля підвищення загальної калорійності палива. Найбільш економічно привабливими для впровадження в умовах промисловості методами $€$ використання технічної та аміачної води, а також відходів процесів травлення сталі у вигляді сульфату заліза.

\section{Бібліографічний опис}

1. Биогазовые установки. Практическое пособие [Електронний ресурс] - Режим доступу: http://zorgbiogas.ru/upload/pdf/Biogas_plants_Practics.pdf

2. Гелетуха, Г. Г. Перспективи виробництва та використання біогазу в Україні / Г. Г. Гелетуха, П. П. Кучерук, Ю. Б. Матвєєв. - К. : Біоенергетична асоціація України, 2014. - Аналітична записка. - № 11. - 42 с.

3. Частухин В.И. Топливо и теория горения. Підручник для студентів ВУЗів. - К.: Вищ.шк., $1989-233$ с.

4. Баадер, В. Биогаз: теория и практика / пер. с нем. и предисловие Серебряного М.И., - М. : Колос, 1982. 149 c.

5. Гуревич М.О., Куріс Ю.В. Властивості спалювання біогазу та визначення рівноважних продуктів згоряння // Фаховий журнал «Альтернативна енергетика», м. Київ. - 2009. - с. 60 - 66. 
6. Трусов Б. Г. Моделирование химических и фразовых равновесий при высоких температурах (ASTRA-4/pc). - М.: МГТУ, 1994. - 50 с.

7. Ткаченко С.І., Степанов Д.В. Удосконалення технології спалювання біогазу отриманого при процесах біоконверсії / Фаховий журнал "Новини Енергетики", м. Київ. - 2007. — № 2. - c. 36-42.

8. Колобродов В. Г. Повышение качества биогаза // Экотехнологии и ресурсозбережение. - 2004. - №5. - с. 51-55.

1. Biogazovye ustanovki. Prakticheskoe posobie [Elektronnij resurs] - Rezhim dostupu: http://zorgbiogas.ru/upload/pdf/Biogas_plants_Practics.pdf

2. Geletuha, G. G. Perspektivi virobnictva ta vikoristannya biogazu v Ukrayini / G. G. Geletuha, P. P. Kucheruk, Yu. B. Matvyeyev. - K. : Bioenergetichna asociaciya Ukrayini, 2014. - Analitichna zapiska. - № 11. - $42 \mathrm{~s}$.

3. Chastuhin V.I. Toplivo i teoriya goreniya. Pidruchnik dlya studentiv VUZiv. - K.: Vish.shk., 1989 - 233 s.

4. Baader, V. Biogaz: teoriya i praktika / per. s nem. i predislovie Serebryanogo M.I., - M. : Ko-los, 1982. - 149 s.

5. Gurevich M.O., Kuris Yu.V. Vlastivosti spalyuvannya biogazu ta viznachennya rivnovazhnih produktiv zgoryannya // Fahovij zhurnal «Alternativna energetika», m. Kiyiv. - 2009. - s. $60-66$.

6. Trusov B. G. Modelirovanie himicheskih i fazovyh ravnovesij pri vysokih temperaturah (ASTRA-4/rs). - M.: MGTU, 1994. $-50 \mathrm{~s}$.

7. Tkachenko S.I., Stepanov D.V. Udoskonalennya tehnologiyi spalyuvannya biogazu otrimanogo pri procesah biokonversiyi / Fahovij zhurnal "Novini Energetiki”, m. Kiyiv. — 2007. — № 2. — s. 36-42.

8. Kolobrodov V. G. Povyshenie kachestva biogaza // Ekotehnologii i resursozberezhenie. - 2004. - №5. - s. 51-55.

Стаття поступила:30.08.2019 